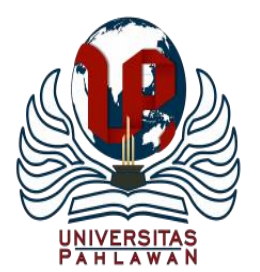

Jurnal Basicedu Volume 5 Nomor 1 Tahun 2021 Halaman 288-300

JURNALBASICEDU

Research \&Learningin Elementary Education

https://jbasic.org/index.php/basicedu

\title{
Pengembangan Video Pembelajaran dengan Menggunakan Aplikasi PowerDirector 18 di Sekolah Dasar
}

\author{
Aulya Ilsa ${ }^{1}$, Farida $\mathbf{F}^{2}$, Mardiah Harun ${ }^{3}$ \\ Program Studi Pendidikan Dasar, Pascasarjana Universitas Negeri Padang, Indonesia ${ }^{1,2,3}$ \\ E-mail : aulyailsa@ rocketmail.com ${ }^{1} \underline{\text { faridafachruddin67@ gmail.com }}^{2} \underline{\text { mardiah_harun@yahoo.com }}^{3}$
}

\begin{abstract}
Abstrak
Penelitian ini dilatarbelakangi oleh proses pembelajaran yang terbatas di masa pandemi. Proses pembelajaran di sekolah dilaksanakan secara daring dan luring. Hal tersebut membuat peserta didik merasa bosan sehingga motivasi belajar berkurang. Penelitian ini bertujuan untuk mendeskripsikan proses pengembangan video pembelajaran dengan menggunakan aplikasi PowerDirector 18 pada materi Lingkaran Matematika kelas VI sekolah dasar yang valid, praktis dan efektif. Jenis penelitian adalah pengembangan menggunakan model umum desain penelitian Plomp yang terdiri atas 3 tahap yaitu preliminary research, prototyping phase, assesment phase. Data uji validitas diperoleh melalui lembar validasi video pembelajaran, RPP. Video pembelajaran terlebih dahulu dievaluasi oleh peneliti sendiri, lalu dilanjutkan validasi oleh validator untuk mendapatkan masukan sehingga diperoleh kevalidan video pembelajaran untuk semua aspek adalah 90\% masuk kategori sangat valid. Berdasarkan uji coba praktikalitas dapat diketahui bahwa video pembelajaran dapat memberikan kemudahan kepada guru dan peserta didik, menarik minat guru dan peserta didik, serta berguna bagi guru untuk memberikan pembelajaran kepada peserta didik, sehingga diperoleh tingkat praktikalitas video pembelajaran adalah 93\% pada kategori sangat praktis. Selanjutnya video pembelajaran memberikan dampak, pengaruh dan hasil yang sangat baik terhadap aktivitas peserta didik yaitu $88,4 \%$, sikap $83 \%$, pengetahuan $84 \%$, dan keterampilan $87 \%$ sehingga secara keseluruhan efektivitas video pembelajaran dikatakan sangat efektif. Disimpulkan bahwa video pembelajaran materi Lingkaran Matematika kelas VI SD telah dinyatakan valid, praktis dan efektif.
\end{abstract}

Kata kunci: video pembelajaran, aplikasi PowerDirector 18, materi lingkaran

\section{Abstract}

This research was motivated by a limited learning process during the pandemic. The learning process at school is carried out online and offline. This makes students feel bored so that learning motivation is reduced. This study aims to describe the process of developing instructional videos using the PowerDirector 18 application in the Mathematics Circle material of class VI elementary schools which is valid, practical and effective. This type of research is development using a general model of the Plomp research design which consists of 3 stages, namely preliminary research, prototyping phase, and assessment phase. The validity test data was obtained through the validation sheet of learning videos, lesson plans. The instructional video was first evaluated by the researcher himself, then continued with validation by the validator to get input so that the validity of the learning video for all aspects was $90 \%$ in the very valid category. Based on practicality trials, it can be seen that instructional videos can make it easy for teachers and students, attract teachers and students, and are useful for teachers to provide learning to students, so that the practical level of learning videos is $93 \%$ in the very practical category. Furthermore, the instructional videos have a very good impact, influence and results on the activities of students, namely $88.4 \%, 83 \%$ attitude, $84 \%$ knowledge and $87 \%$ skills so that the overall effectiveness of the learning videos is said to be very effective. It is concluded that the learning video material for the 6th grade Mathematics circle of SD has been declared valid, practical and effective.

Keywords: learning videos, PowerDirector 18 app, circle material

Copyright (c) 2021 Aulya Ilsa, Farida F, Mardiah Harun

$\triangle$ Corresponding author

Address : Pascasarjana Universitas Negeri Padang

Email : aulyailsa@rocketmail.com

ISSN 2580-3735 (Media Cetak)

Phone :-

DOI $\quad:$ https://doi.org/10.31004/basicedu.v5i1.643 
289 Pengembangan Video Pembelajaran dengan Menggunakan Aplikasi Powerdirector 18 di Sekolah Dasar - Aulya Ilsa, Farida F, Mardiah Harun

DOI : https://doi.org/10.31004/basicedu.v5i1.643

\section{PENDAHULUAN}

Matematika untuk tingkatan Sekolah Dasar (SD) merupakan tingkat Matematika Dasar. Matematika merupakan ilmu yang harus dikuasai oleh siswa karena memiliki peranan penting dalam kehidupan seperti berhitung, mengukur, dsb. Sesuai dengan pendapat (Fathani 2009) menyatakan bahwa Matematika itu penting bagi siswa baik sebagai alat bantu, sebagai ilmu, sebagai pembentuk sikap maupun sebagai pembimbing pola pikir. Mengingat Matematika sangat penting dalam kehidupan sehari-hari maka Matematika perlu dipahami dan dikuasai oleh semua lapisan masyarakat tak terkecuali siswa sekolah dasar.

Belajar Matematika dapat mengembangkan kemampuan daya pikir, membuat perhitungan yang matang dalam mengambil keputusan dan sarana dalam memecahkan permasalahan. Tujuan Matematika yaitu melatih siswa berpikir dan bernalar, mengembangkan kreatifitas dan mengembangkan kemampuan memecahkan masalah. Untuk itu sebagai seorang guru harus memikirkan ide-ide agar pembelajaran Matematika membuat siswa bersemangat, merasa senang namun tetap santai dalam pembelajaran Matematika seperti penggunaan media pembelajaran. Martini, Edy dan Choli) menyebutkan bahwa "penggunaan media secara keseluruhan mampu membuat siswa bersemangat, merasa senang, dapat bekerjasama dan melatih kemandirian dalam proses pembelajaran Matematika".

Proses pembelajaran Matematika di sekolah saat ini tidak berlangsung seperti biasanya dikarenakan dunia saat ini sedang dilanda pandemi Covid-19 tidak terkecuali Indonesia. Untuk terbebas dari pandemi Covid-19 tersebut pemerintah masing-masing negara membuat kebijakan untuk menutup negaranya (lockdown) dan tidak memperbolehkan warga untuk berkumpul di tempat keramaian. Sekolah-sekolah, lembaga pemerintahan maupun swasta ditutup untuk sementara agar pandemi segera berakhir. Sesuai dengan UU No. 06/2018, bahwa "Presiden meminta seluruh komponen bangsa untuk melakukan pembatasan kegiatan".

Dampak dari penutupan sekolah berimbas ke proses pembelajaran di kelas yang tidak dapat dilakukan. Namun pemerintah mengizinkan untuk belajar dari rumah dengan metode belajar jarak jauh. Untuk wilayah provinsi Sumatera Barat menerapkan pembelajaran daring dan luring disesuaikan dengan kondisi siswa dan sekolah masing-masing daerah. Namun metode pembelajaran jarak jauh memiliki keterbatasan sehingga membuat kesulitan dalam mengontrol pembelajaran oleh guru dan membuat siswa merasa bosan.

Berdasarkan hasil wawancara penulis dengan guru pada Kamis 20 Agustus 2020 menyimpulkan bahwa peserta didik merasa jenuh akan pembelajaran daring, mereka bosan dengan pemberian tugas setiap harinya. Peserta didik juga menjadi malas dalam mengerjakan tugas, hal tersebut menjadikan pengumpulan tugas menjadi sangat terlambat sehingga menjadikan guru sulit melakukan penilaian.

Pembelajaran dilakukan melalui media sosial WhatsApp (WA) sebagai kontrol guru 
290 Pengembangan Video Pembelajaran dengan Menggunakan Aplikasi Powerdirector 18 di Sekolah Dasar - Aulya Ilsa, Farida F, Mardiah Harun

DOI : https://doi.org/10.31004/basicedu.v5i1.643

terhadap siswa dalam hal pemberian tugas. Siswa menjemput ke sekolah tugas yang akan dikerjakan dan dikembalikan satu minggu setelah tugas diambil. Guru kurang memanfaatkan media pembelajaran seperti video pembelajaran untuk membantu siswa dalam memahami materi yang akan dipelajari. Sesuai dengan pendapat Hilna, dkk (2020) menyatakan bahwa "pembelajaran daring dirasa kurang efektif bagi guru terutama untuk anak usia SD, karena pembelajaran dilaksanakan secara daring maka guru merasa kurang maksimal dalam memberikan materi pembelajaran sehingga menjadikan materi tidak tuntas dan penggunaan media pembelajaran dalam pembelajaran daring juga dirasa belum maksimal”.

Berdasarkan hasil penelitian yang dilakukan Taufik (2016) menyatakan bahwa hasil belajar siswa menggunakan video pembelajaran lebih tinggi dari pada pembelajaran konvensional. Jadi dapat disimpulkan bahwa penggunaan video pembelajaran pada proses pembelajaran daring juga bisa meningkatkan hasil belajar siswa.

Kenyataan di lapangan yang peneliti temui di sekolah yang berbeda yaitu SD Betha Plus Kota Padang berdasarkan hasil wawancara dengan guru pada Kamis 20 Agustus 2020 melalui WhatsApp bahwa ia pernah mencoba melaksanakan pembelajaran dengan video pembelajaran hanya sebatas bisa didengar dan dilihat, namun tidak mengajak siswa untuk terlibat aktif selama video pembelajaran ditayangkan. Begitu juga dengan video pembelajaran yang ada di YouTube bahwa video pembelajarannya hanya memuat materi dan masalah yang akan di selesaikan oleh siswa. Jarang video pembelajaran yang membuat siswa aktif untuk mencobakan/menemukan konsep sendiri. Video pembelajaran seharusnya membuat siswa untuk aktif dalam pembelajaran.

Pelaksanaan video pembelajaran agar membuat siswa aktif harus melihat karakteristik siswa kelas VI yaitu segi sosioemosional, segi psikomotor dan segi kognitif sejalan dengan pernyataan Confucius bahwa "ada beberapa bobot penting dalam pembelajaran aktif yaitu what $i$ hear, i forget; what i see, $i$ remember; what $i$ do, $i$ understand". Yang artinya: apa yang saya dengar, saya lupa; apa yang saya lihat, saya ingat; apa yang saya lakukan, saya paham. Di dalam proses pembelajaran dengan menggunakan video pembelajaran seharusnya dapat mengoptimalkan pembelajaran aktif sesuai yang diungkapkan oleh Confusius tersebut.

Video pembelajaran yang baik membuat siswa bisa mendengar, melihat, dan bekerja/ menemukan sendiri. Nantinya peneliti akan merancang video pembelajaran dengan sebuah percobaan yang akan dilakukan oleh siswa dirumah sehingga siswa akan semakin mengerti dengan materi yang dipelajari dengan artian siswa tersebut akan berbuat sehingga dia akan paham.

Pengembangan media video pembelajaran akan dikembangkan pada materi mengenai Lingkaran. Selain itu, siswa juga akan disuruh untuk mencoba sendiri di rumah agar menemukan konsep lingkaran tersebut. Dalam pembelajaran dengan menggunakan video pembelajaran tersebut peneliti akan menggunakan model pembelajaran inkuiri terbimbing untuk membantu dalam mengkondisikan siswa belajar secara virtual. 
291 Pengembangan Video Pembelajaran dengan Menggunakan Aplikasi Powerdirector 18 di Sekolah Dasar - Aulya Ilsa, Farida F, Mardiah Harun

DOI : https://doi.org/10.31004/basicedu.v5i1.643

Basyirudin Usman dan Asnawir (2002:98) mengemukakan bahwa "video pembelajaran yang baik memiliki ciri-ciri sebagai berikut: (a) sesuai dengan tema pembelajaran, (b) dapat menarik minat peserta didik, (c) benar dan autentik, (d) up to date dalam setting, pakaian dan lingkungan, (e) sesuai dengan tigkat kematangan peserta didik, (f) perbendaharaan bahasa yang benar". Ada banyak kelebihan video ketika digunakan sebagai media pembelajaran di antaranya menurut Nugent (dalam Smaldino, dkk 2008:310) bahwa "video merupakan media yang cocok untuk berbagai macam pembelajaran, seperti kelas, kelompok kecil, bahkan satu peserta didik seorang diri sekalipun". Hal itu, tidak dapat dilepaskan dari kondisi para peserta didik saat ini yang tumbuh berkembang dalam dekapan budaya teknologi. Sedangkan menurut Azhar Arsyad (2004:37-52) bahwa "karakteristik video pembelajaran yaitu: (a) dapat disimpan dan digunakan berulang kali, (b) harus memiliki teknik khusus, untuk pengaturan urutan baik dalam hal penyajian maupun penyimpanan, (c) pengoperasian relatif mudah, (d) dapat menyajikan peristiwa masa lalu atau peristiwa di tempat lain.

Prosedur pengembangan video pembelajaran menurut Cheppy Riyana (2007:1720) terbagi menjadi dua yaitu : (1) kerangka (out line) media video yang terdiri atas pendahuluan, tayangan pembuka, pengantar, isi video, dan penutup. (2) keterlibatan tim yaitu ahli substansi, ahli media instruksional, ahli metode instruksional, sutradara, ahli computer editing dan desain grafis, ahli sound director.
Menurut menurut Daryanto (2010:104-106) langkah-langkah umum yang ditempuh dalam pembuatan video pembelajaran yaitu dengan menulis naskah video pembelajaran yang dipaparkan sebagai berikut: (1) temukan ide, (2) rumusan tujuan, (3) melakukan survei, (4) buat garis besar isi, (5) buat sinopsis, (6) buat treatment, (7) buat storyboard, (8) menulis naskah.

Langkah praktis menyusun naskah menurut Jaka Warsihna (2009:16-17) adalah: (a) lihat indikator atau materi yang akan disajikan, pilih format sajian sesuai karakteristik materi yang akan disajikan,(b) bumper tune, penanda singkat sebuah program acara, (d) teaser (pembuka) cuplikan gambar yang akan dibahas, (e) isi bagian visual dengan perintah deskripsi, (f) utamakan visual gerak, berwarna, tiga dimensi dan detail, (g) sesuai narasi, (h) penulisan caption sesuai EYD, singkat dan tidak lebih lima baris, (i) sajikan materi yang menarik, jelas, mudah diingat, (j) pengulangan tidak sama persis dengan sajian materi, (k) latihan dibuat dalam bentuk soal tertutup sebagai bentuk penguat sajian materi, (l) audio sebagai penguat atau penjelasan visual yang belum jelas, (m) narasi tidak menggurui, disesuaikan dengan situasi dan kondisi.

Rancangan video pembelajaran yang akan dibuat saat ini adalah video pembelajaran mengenai materi Lingkaran yang terbagi menjadi 3 buah video pembelajaran yaitu video pembelajaran unsur-unsur lingkaran, video pembelajaran keliling lingkaran, dan video pembelajaran luas lingkaran, dimana untuk pemutaran video \pm 10 menit. Adapun isi dari video pembelajaran tersebut dapat dijabarkan sebagai berikut : 
292 Pengembangan Video Pembelajaran dengan Menggunakan Aplikasi Powerdirector 18 di Sekolah Dasar - Aulya Ilsa, Farida F, Mardiah Harun

DOI : https://doi.org/10.31004/basicedu.v5i1.643

a. Pembukaan oleh peneliti sendiri dengan menjabarkan tentang materi yang akan dipelajari, tujuan pembelajaran, dan hal yang harus dicapai oleh peserta didik untuk mendapatkan hasil belajar yang baik. Selain itu, sedikit penjelasan tentang materi yang akan dipelajari.

b. Menyuruh peserta didik untuk menyiapkan bahan untuk melakukan percobaan sederhana.

c. Peragaan video tentang materi lingkaran yang telah ada dan dikembangkan oleh peneliti. Setelah melihat video tersebut peserta didik bisa melakukan praktik di rumah sendiri mencobakan sendiri agar semakin paham dengan unsur-unsur lingkaran. Semua kegiatan praktik tersebut bisa dilihat dari video call atau peserta didik memilih untuk merekam sendiri aktivitasnya.

d. Diberikan beberapa tes kepada peserta didik mengenai materi lingkaran dalam bentuk essay.

Pembuatan video pembelajaran menggunakan aplikasi PowerDirector 18. Menurut Wikipedia bahwa PowerDirector adalah perangkat lunak pengeditan video yang dikembangkan oleh Cyberlink. PowerDirector berjalan pada Windows 7 hingga Windows 10, dengan versi 64-bit yang direkomendasikan. Dirilis pertama kali versi 4.0 pada Januari 2005 yang disediakan untuk komputer dan rilis terakhir September 2019 untuk versi 18.0. Sedangkan pada 4 Juni 2014 dirilis untuk pertama kalinya versi Android. PowerDirector memiliki 5 edisi ritel yang berbeda termasuk Director Suite, Ultimate Suite, Ultimate, Ultra dan Deluxe (alias standar di Jepang).

Video pembelajaran yang akan dibuat adalah video pembelajaran Matematika kelas VI yang terdiri atas 5 buah video pembelajaran sesuai dengan sub materi Lingkaran yaitu (a) unsur-unsur lingkaran, (b) keliling lingkaran, (c) luas lingkaran, (d) panjang busur, keliling dan luas juring, (d) bangun campuran. Video pembelajaran materi lingkaran Matematika kelas VI SD akan diajarkan kepada peserta didik dengan model pembelajaran inkuiri terbimbing yang dilakukan saat pembelajaran secara virtual. Proses pembelajaran inkuiri terbimbing dimana guru membimbing peserta didik dalam aktivitas untuk menemukan suatu konsep baru. Sesuai dengan pernyataan Isrok`atun (2018:53) bahwa "model pembelajaran inkuiri merupakan suatu pembelajaran yang menjadikan peserta didik sebagai subjek belajar atau disebut student centered. Peserta didik melakukan aktivitas untuk menemukan suatu konsep baru".

Menurut Sanjaya(2006:194-195) bahwa "karakteristik model pembelajaran inkuiri terbimbing adalah (a) menekankan pada aktivitas peserta didik secara maksimal untuk mencari dan menemukan. (b) seluruh aktivitas yang dilakukan peserta didik diarahkan untuk mencari dan menemukan jawaban sendiri dari sesuatu yang dipertanyakan. (c) tujuannya untuk mengembangkan kemampuan berpikir sistematis, logis, kritis atau mengembangkan intelektual sebagai bagian dari proses mental". Isrok`atun (2018:55) bahwa penjelasan setiap proses pada langkah-langkah pembelajaran inkuiri terbimbing 
293 Pengembangan Video Pembelajaran dengan Menggunakan Aplikasi Powerdirector 18 di Sekolah Dasar - Aulya Ilsa, Farida F, Mardiah Harun

DOI : https://doi.org/10.31004/basicedu.v5i1.643

yakni adalah: (a) merumuskan masalah, (b) merumuskan hipotesis, (c) mengumpulkan data, (d) menguji hipotesis, (e) menarik kesimpulan.

\section{METODE}

Penelitian ini adalah penelitian pengembangan atau yang dikenal dalam bahasa Inggrisnya Research and Development (R\&D) adalah metode penelitian yang digunakan untuk menghasilkan suatu produk, atau menyempurnakan produk yang telah ada dan menguji keefektifan produk tersebut.

Menurut Putra (2012:67) "R\&D adalah metode penelitian yang secara sengaja, sistematis bertujuan/diarahkan untuk mencari temukan, merumuskan, memperbaiki, mengembangkan, menghasilkan, menguji keefektifan produk, model, metode/strategi/cara, jasa, prosedur tertentu yang lebih unggul, baru, efektif, efisien, produktif, dan bermakna".

Selanjutnya menurut Sugiyono (2009:407) " $R \& D$ adalah metode penelitian yang digunakan untuk menghasilkan produk tertentu, dan menguji keefektifan produk tersebut". Senada dengan itu Trianto (2011:206) juga mengemukakan bahwa, "R\&D adalah rangkaian proses atau langkahlangkah dalam rangka mengembangkan suatu produk baru atau menyempurnakan produk yang telah ada agar dapat dipertanggung".

Penelitian ini merupakan penelitian pengembangan yaitu pengembangan video pembelajaran pada materi lingkaran kelas VI SD. pengembangan video pembelajaran harus memenuhi kriteria valid, praktis, efektif. Model pengembangan dalam penelitian ini mengikuti model umum desain penelitian menurut Plomp (2013:19)) yang terdiri atas 3 fase yaitu preliminary research, protothyping phase, assesment stage.

\section{Tahap Preliminary Research (Analisis Pendahuluan)}

Pada fase ini dilakukan telaah kurikulum yang digunakan oleh sekolah uji coba. Pengembangan video pembelajaran dikembangkan sesuai dengan Kurikulum 2013. Analisis kurikulum dilakukan dengan menganalisis Kompetensi Inti (KI), Kompetensi Dasar (KD), dan indikator yang harus dicapai peserta didik. Selain analisis kurikulum dilakukan juga analisis video pembelajaran dengan menyesuaikan dengan bahan ajar peserta didik, selanjutnya analisis konsep dan analisis peserta didik.

\section{Tahap Protothyping Phase (Perancangan)}

Desain awal prototype dievaluasi dengan metode self evaluation bersama salah seorang guru SDN 29 Kotohilalang. Hasil self evaluation proyotype dilanjutkan dengan expert review kepada 3 orang ahli. Setelah validasi oleh expert review dilanjutkan dengan metode one to one evaluation dan small group discussion kepada peserta didik. Selanjutnya hasil evaluasi dilanjutkan dengan field test evaluation ke peserta didik SDN 29 Kotohilalang untuk melihat praktikalitas.

\section{Tahap Assesment Stage (Penilaian)}

Untuk mengetahui efektivitas dilakukan uji coba dengan metode field test evaluation di SD 
294 Pengembangan Video Pembelajaran dengan Menggunakan Aplikasi Powerdirector 18 di Sekolah Dasar - Aulya Ilsa, Farida F, Mardiah Harun

DOI : https://doi.org/10.31004/basicedu.v5i1.643

Negeri 29 Kotohilalang Kec. Ampek Angkek dan SD Betha Plus Kota Padang untuk melihat hasil belajar aspek pengetahuan. Data efektivitas diperoleh dari data aktivitas peserta didik dan hasil belajar yang diberikan kepada peserta didik dilihat dari aspek sikap, aspek pengetahuan dan aspek keterampilan.

\section{HASIL DAN PEMBAHASAN}

Hasil validasi terhadap seluruh aspek yang diamati, disajikan dalam bentuk tabel, selanjutnya dicari rerata skor tersebut menggunakan rumus yang diadaptasi dari Muliyardi, 2006:82.

Rerata yang didapatkan dikonfirmasi dengan kriteria yang ditetapkan. Cara mendapatkan kriteria tersebut adalah dengan menetapkan rentang skor dimulai dari 1 sampai 5. Rentang skor tersebut dibagi menjadi 5 kelas interval. Kriteria setiap interval dikategorikan atas lima tingkatan seperti pada tabel berikut :

Tabel 1. Kriteria Penilaian Kevalidan

\begin{tabular}{|c|c|l|}
\hline No. & $\begin{array}{c}\text { Tingkat Pencapaian } \\
(\boldsymbol{\%})\end{array}$ & \multicolumn{1}{|c|}{ Kategori } \\
\hline 1 & $81-100$ & Sangat valid \\
\hline 2 & $61-80$ & Valid \\
\hline 3 & $41-60$ & Cukup Valid \\
\hline 4 & $21-40$ & Kurang Valid \\
\hline 5 & $0-20$ & Tidak Valid \\
\hline
\end{tabular}

(dimodifikasi dari Riduwan, 2006:87)

\section{Uji Kepraktisan}

Dari hasil pengisian angket dianalisis terlebih dahulu diberikan penskoran terhadap pilihan jawaban yang disediakan untuk setiap butir pernyataan. Rentang skor dimulai dari 1 skor rendah sampai 4 skor tinggi. Angket tersebut disusun dalam bentuk skala likert. Skala likert ini disusun dengan kategori positif sesuai dengan pendapat Sudjana (2005:109), sehingga pernyataan positif memperoleh bobot tertinggi dengan rincian berikut:

$\begin{array}{ll}\text { Sangat Setuju } & \text { bobot } 4 \\ \text { Setuju } & \text { bobot } 3 \\ \text { Tidak setuju } & \text { bobot } 2 \\ \text { Sangat tidak setuju } & \text { bobot } 1\end{array}$

Rerata yang didapatkan dikonfirmasi dengan kriteria yang ditetapkan. Cara mendapatkan kriteria tersebut adalah dengan menetapkan rentang skor dimulai dari 1 sampai 5 . Rentang skor tersebut dibagi menjadi 5 kelas interval.

\section{Tabel 2. Kriteria Kepraktisan Video Pembelajaran}

\begin{tabular}{|c|c|c|}
\hline No. & $\begin{array}{c}\text { Tingkat } \\
\text { Pencapaian }(\%)\end{array}$ & Kategori \\
\hline 1 & $81-100$ & Sangat praktis \\
\hline 2 & $61-80$ & Praktis \\
\hline 3 & $41-60$ & Cukup praktis \\
\hline 4 & $21-40$ & Kurang praktis \\
\hline 5 & $0-20$ & Tidak praktis \\
\hline
\end{tabular}

(dimodifikasi dari Riduwan, 2006:87)

\section{Uji Efektivitas}

Uji Efektifitas dikumpulkan melalui lembar observasi aktivitas peserta didik dan nilai dari tes hasil belajar menggunakan video pembelajaran tentang materi Lingkaran. Teknik analisis data yang digunakan untuk mengukur efektivitas penggunaan video pembelajaran adalah sebagai berikut: 
295 Pengembangan Video Pembelajaran dengan Menggunakan Aplikasi Powerdirector 18 di Sekolah Dasar - Aulya Ilsa, Farida F, Mardiah Harun

DOI : https://doi.org/10.31004/basicedu.v5i1.643

\section{Aktivitas Peserta Didik}

Lembar observasi aktivitas peserta didik dianalisis dengan teknik analisis deskriptif kuantitatf, yaitu dengan cara menghitung presentase peserta didik yang terlibat dalam setiap aktifitas yang telah ditentukan. Persentase aktivitas peserta didik dideskripsikan secara kualitatif dengan kategori sebagai berikut:

Tabel 3. Kriteria Aktivitas Peserta Didik

\begin{tabular}{|l|c|c|c|}
\hline No & $\begin{array}{c}\text { Tingkat } \\
\text { Pencapaian }(\boldsymbol{\%})\end{array}$ & Kategori & Kategori \\
\hline 1 & $81-100$ & $\begin{array}{c}\text { Sangat } \\
\text { tinggi }\end{array}$ & $\begin{array}{c}\text { Sangat } \\
\text { efektif }\end{array}$ \\
\hline 2 & $61-80$ & Tinggi & Efektif \\
\hline 3 & $41-60$ & Sedang & $\begin{array}{c}\text { Cukup } \\
\text { Efektif }\end{array}$ \\
\hline 4 & $21-40$ & Rendah & $\begin{array}{c}\text { Kurang } \\
\text { Efektif } \\
\text { Tidak } \\
\text { Efektif }\end{array}$ \\
\hline 5 & $0-20$ & $\begin{array}{c}\text { Sangat } \\
\text { rendah }\end{array}$ & \\
\hline
\end{tabular}

\section{Hasil Belajar}

Ada tiga aspek yang dilihat untuk tes hasil belajar, yaitu aspek sikap, aspek pengetahuan, dan aspek keterampilan. Untuk penilaian semua aspek tersebut mengacu pada penilaian kurikulum 2013.

\section{Hasil Belajar Aspek Sikap}

Hasil belajar aspek sikap ditafsirkan dari hasil pengukuran terhadap kriteria yang telah ditetapkan. Analisis data hasil belajar peserta didik pada ranah sikap, persentase ketuntasan hasil belajar dengan rumus yang mengacu pada Arikunto (2012:35) . Kategori hasil belajar ranah sikap ditentukan dari acuan pada tabel dibawah ini:
Tabel 4. Kategori Hasil Belajar Ranah Sikap

\begin{tabular}{|c|c|c|}
\hline $\begin{array}{c}\text { Persentase } \\
(\boldsymbol{\%})\end{array}$ & $\begin{array}{c}\text { Kriteria } \\
\text { Aktivitas }\end{array}$ & Konversi \\
\hline $76-100$ & Sangat baik & Sangat efektif \\
\hline $75-51$ & Baik & Efektif \\
\hline $50-26$ & Cukup baik & Cukup efektif \\
\hline $25-0$ & Tidak baik & Tidak efektif \\
\hline
\end{tabular}

(dimodifikasi Riduwan, $2006: 89$ )

\section{Hasil Belajar Aspek Pengetahuan}

Aspek pengetahuan dinilai dari tes hasil belajar berupa essay yang diberikan setiap kali pembelajaran. Hasil belajar yang diperoleh oleh peserta didik dibandingkan dengan Kriteria Ketuntasan Minimal (KKM) yaitu 75 yang telah ditetapkan oleh sekolah. Jika peserta memperoleh nilai sama atau melebihi KKM, maka peserta didik tersebut dikatakan telah tuntas dalam belajar. Sebaliknya, jika kurang dari KKM maka peserta didik tersebut belum tuntas belajar. Pengembangan video pembelajaran ini dikatakan efektif jika lebih dari $75 \%$ peserta didik mendapatkan nilai $\geq$ KKM. Untuk mengetahui ketuntasan hasil belajar peserta didik dihitung dengan menggunakan rumus menurut Purwanto (2006:102) .

\section{Hasil Belajar Aspek Keterampilan}

Aspek keterampilan dinilai dari LKPD yang dikerjakan oleh peserta didik mengacu kepada rubrik penilaian keterampilan. Kriteria menggunakan skala Likert dengan penskoran tertinggi adalah 4. Nilai aspek psikomotor didapatkan dengan menggunakan rumus menurut Anas (2005:43) . Kategori efektivitas bahan ajar aspek keterampilan dapat dilihat pada tabel sebagai berikut: 
296 Pengembangan Video Pembelajaran dengan Menggunakan Aplikasi Powerdirector 18 di Sekolah Dasar - Aulya Ilsa, Farida F, Mardiah Harun

DOI : https://doi.org/10.31004/basicedu.v5i1.643

Tabel 5. Kategori Penilaian Keterampilan Siswa

\begin{tabular}{|c|c|}
\hline Interval & Konversi \\
\hline $76-100$ & Sangat Efektif \\
\hline $75-51$ & Efektif \\
\hline $50-26$ & Cukup Efektif \\
\hline $25-0$ & Kurang Efektif \\
\hline
\end{tabular}

(diadaptasi dari Riduwan dan Sunarto, 2007:22)

\section{Tahap Analisis Pendahuluan (Preliminary}

\section{Research)}

Tahapan ini dilakukan sebelum mengembangkan dan merancang sebuah produk. Pada tahapan ini dilakukan identifikasi masalah serta kebutuhan dalam pelaksanaan pembelajaran di Sekolah Dasar. Adapun langkah-langkah yang dilakukan yaitu:

\section{Analisis kurikulum}

Analisis kurikulum dilakukan dengan cara menganalisis Kompetensi Inti (KI) pengetahuan dan keterampilan dengan Kompetensi Dasar (KD). Berdasarkan analisis $\mathrm{KI}$ dan $\mathrm{KD}$ yang terdapat pada kurikulum tidak mengidentifikasi perubahan dikarenakan KI dan KD pada kurikulum 2013 dapat diikuti untuk membuat video pembelajaran. Berdasarkan KD yang telah dianalisis tersebut, kemudian disusun indikator-indikator yang akan dicapai pada setiap KD. Indikator yang dirancang menuntut peserta didik untuk berpikir dan aktif dalam belajar tidak hanya menggunakan konsep yang telah ada namun peserta didik akan mencoba menemukan sendiri konsep Matematika tersebut

\section{Analisis bahan ajar/video pembelajaran}

Pembuatan video pembelajaran dimulai dengan cara mencermati bahan ajar peserta didik dan membandingkannya dengan video pembelajaran tentang materi lingkaran yang peneliti miliki. Setelah mencermati isi dari bahan ajar dan video pembelajaran penulis menganalisis kekurangan-kekurangan dari video pembelajaran yang diamati. Kekurangan video pembelajaran yang telah dianalisis di antaranya; (1) video pembelajaran tersebut dengan intonasi suara yang cepat, sehingga kurang pas untuk didengarkan kepada anak kelas VI SD, (2) tidak memiliki jeda waktu kepada peserta didik untuk berpikir, menganalisis atau memahami tentang materi yang dipelajari, (3) terlalu banyak kata-kata yang di jabarkan di dalam video sehingga akan membuat peserta didik bosan untuk membaca yang berakibat kepada peserta didik yang tidak akan mengerti tentang materi yang dipelajari

\section{Analisis Konsep}

Analisis konsep dikembangkan untuk merencanakan urutan-urutan pengajaran bagi tercapainya sebuah konsep. Konsep disusun secara sistematis dengan mengaitkan konsep yang satu dengan konsep lain yang relevan sehingga membentuk sebuah konsep. Contohnya untuk memahami konsep keliling lingkaran dan luas lingkaran terlebih dahulu peserta didik harus mamahami konsep nilai phi $(\pi)$.

\section{Analisis peserta didik.}

Peserta didik kelas VI sekolah dasar pada umumnya berusia 11-13 tahun. Peserta didik pada usia tersebut lebih menyukai objek yang bersifat nyata dan berwarna-warni, dari hasil wawancara diketahui bahwa pada umumnya peserta didik 
297 Pengembangan Video Pembelajaran dengan Menggunakan Aplikasi Powerdirector 18 di Sekolah Dasar - Aulya Ilsa, Farida F, Mardiah Harun

DOI : https://doi.org/10.31004/basicedu.v5i1.643

menyukai pembelajaran Matematika tetapi mereka terkendala dalam memahami materi Matematika sesuai dengan pernyataan guru bahwa siswa kurang jeli dalam membaca/memahami kalimat tentang materi yang dipelajari.

\section{Tahap Pengembangan (Prothotype Phase)}

\section{Prototype 1}

Prototype yang dirancang divalidasi oleh Self Evaluation dengan bantuan guru umumnya berkaitan dengan proses perekaman pembelajaran, serta kontrol soal untuk dikerjakan oleh peserta didik. Selanjutnya dilakukan validasi oleh 3 orang pakar ahli dimana para pakar memberikan saran untuk perbaikan mengenai waktu jeda untuk siswa berpikir agar ditambah, tampilan video pembelajaran dengan background yang berbeda, animasi pada video pembelajaran dikurangi agar tidak terlalu banyak sehingga peserta didik dapat fokus pada konsep yang ditampilkan. Penilaian validator untuk beberapa aspek diantaranya aspek kelayakan isi, aspek kebahasaan, aspek penyajian, aspek kegrafikan. Untuk penilaian oleh validator secara keseluruhan dapat dilihat pada tabel berikut ini :

Tabel 6. Hasil Validasi Video Pembelajaran

\begin{tabular}{|l|l|c|c|c|}
\hline No & Validator & Jumlah & $\%$ & Kategori \\
\hline 1. & Validator 1 & 87 & $87 \%$ & Sangat Valid \\
\hline 2. & Validator 2 & 91 & $91 \%$ & Sangat Valid \\
\hline 3. & Validator 3 & 92 & $92 \%$ & Sangat Valid \\
\hline \multicolumn{6}{|c|}{ Rata-rata Persentase } & $90 \%$ & Sangat Valid \\
\hline
\end{tabular}

\section{Prototype 2 (One To One Evaluation)}

Video pembelajaran tersebut diberikan kepada 3 orang peserta didik dengan kemampuan sedang hingga tinggi, dimana peserta didik ini telah menamatkan pembelajaran lingkaran tersebut. Dari hasil angket dan wawancara diperoleh bahwa peserta didik sudah memahami video pembelajaran materi lingkaran tersebut dikarenakan video pembelajaran yang dapat diputar ulang hingga peserta didik paham materi yang dipelajari.

\section{Prototype 3 (Small Group Evaluation)}

Evaluasi dilakukan dengan cara melakukan Small Group Discussion atau evaluasi kelompok kecil dengan mempraktekkan pembelajaran menggunakan video pembelajaran yang telah dirancang kepada 5 orang peserta didik yang telah menamatkan pembelajaran lingkaran. Hasil evaluasi diperoleh dengan angket dan wawancara yang menunjukkan bahwa video pembelajaran materi lingkaran Matematika kelas VI sudah praktis digunakan peserta didik dalam pembelajaran serta dapat dilanjutkan dengan uji coba produk ke lapangan.

\section{Prototype 4 (Uji Lapangan/ Field Test)}

Video pembelajaran materi Lingkaran Matematika kelas VI SD akan diuji cobakan di SD 29 Kotohilalang dengan jumlah peserta didik sebanyak 15 orang dari 42 orang di 2 kelas. Dikarenakan hanya 15 orang peserta didik yang dapat melakukan pembelajaran secara daring melalui aplikasi Zoom. Data uji coba video pembelajaran diperoleh dari angket praktikalitas respon guru dan respon peserta didik. Untuk hasil praktikalitas respon guru dan peserta didik dapat dilihat sebagai berikut : 
298 Pengembangan Video Pembelajaran dengan Menggunakan Aplikasi Powerdirector 18 di Sekolah Dasar - Aulya Ilsa, Farida F, Mardiah Harun

DOI : https://doi.org/10.31004/basicedu.v5i1.643

Tabel 7. Hasil Praktikalitas Respon Guru

\begin{tabular}{|c|l|c|c|}
\hline No & Aspek Yang Dinilai & $\begin{array}{c}\text { Rata- } \\
\text { rata (\%) }\end{array}$ & Kategori \\
\hline 1. & $\begin{array}{l}\text { Kesesuaian waktu } \\
\text { dan ilustrasi }\end{array}$ & 98 & $\begin{array}{c}\text { sangat } \\
\text { praktis }\end{array}$ \\
\hline 2. & $\begin{array}{l}\text { Kepraktisan } \\
\text { penggunaan }\end{array}$ & 91 & $\begin{array}{c}\text { sangat } \\
\text { praktis }\end{array}$ \\
\hline 3. & Kemudahan & 89 & $\begin{array}{c}\text { sangat } \\
\text { praktis }\end{array}$ \\
\hline \multicolumn{2}{|c|}{ Rata-rata } & 93 & $\begin{array}{c}\text { sangat } \\
\text { praktis }\end{array}$ \\
\hline
\end{tabular}

Tabel 8. Hasil Analisis Angket Respon 15

Orang Peserta Didik terhadap Video Pembelajaran

\begin{tabular}{|l|l|c|c|}
\hline No. & Nama Praktisi & $\begin{array}{c}\text { Tingkat } \\
\text { Pencapaian } \\
(\boldsymbol{\%})\end{array}$ & Kategori \\
\hline 1 & Praktisi 1 & 96 & Sangat Praktis \\
\hline 2 & Praktisi 2 & 90 & Sangat Praktis \\
\hline 3 & Praktisi 3 & 94 & Sangat Praktis \\
\hline \multicolumn{2}{|c|}{ Rata-rata } & $\mathbf{9 3}$ & $\begin{array}{c}\text { Sangat } \\
\text { Praktis }\end{array}$ \\
\hline
\end{tabular}

Berdasarkan tabel hasil respon guru dan peserta didik di atas dapat disimpulkan bahwa video pembelajaran yang dikembangkan telah memiliki kepraktisan sangat baik dari penyajian dan penggunaannya.

\section{Tahap Penilaian (Assesment Stage)}

Pada tahap penilaian ini yang akan dinilai adalah efektivitas video pembelajaran materi Lingkaran Matematika kelas VI SD Negeri 29 Kotohilalang Kecamatan Ampek Angkek Kabupaten Agam dengan jumlah 15 orang peserta didik. Hasil efektivitas dilihat dari aktivitas peserta didik dan hasil belajar peserta didik setelah pembelajaran menggunakan video pembelajaran materi Lingkaran. Penjabaran hasil efektivitas dilihat dari aktivitas dan hasil belajar peserta didik adalah sebagai beikut:
Tabel 9. Pengamatan Aktivitas Peserta Didik

\begin{tabular}{|c|l|c|}
\hline No. & \multicolumn{1}{|c|}{ Aspek } & Persentase \\
\hline 1 & Sikap & $83 \%$ \\
\hline 2 & Pengetahuan & $84 \%$ \\
\hline 3 & Keterampilan & $87 \%$ \\
\hline Rata-rata & $\mathbf{8 5 \%}$ \\
\hline
\end{tabular}

Berdasarkan tabel diatas ditunjukkan pada aktivitas mendengar penjelasan guru dan memperhatikan guru, memperhatikan video pembelajaran materi lingkaran, menanggapi pertanyaan, serta mengerjakan latihan. Kesimpulan dari hasil pengamatan aktivitas peserta didik selama melakukan kegiatan pembelajaran termasuk kategori sangat baik. Maka efektivitas video pembelajaran dilihat dari aktivitas peserta didik dapat dikatakan sangat baik digunakan dalam kegiatan pembelajaran.

Tabel 10. Hasil Belajar Peserta Didik

\begin{tabular}{|l|l|l|l|l|l|l|}
\hline \multirow{2}{*}{ No } & \multirow{2}{*}{$\begin{array}{c}\text { Aspek yang } \\
\text { dinilai }\end{array}$} & $\begin{array}{c}\text { PB } \\
\mathbf{1}\end{array}$ & $\begin{array}{c}\text { PB } \\
\mathbf{2}\end{array}$ & $\begin{array}{c}\text { PB } \\
\mathbf{3}\end{array}$ & $\begin{array}{c}\text { PB } \\
\mathbf{4}\end{array}$ & $\begin{array}{c}\text { Rata } \\
\text { Rata }\end{array}$ \\
\hline 1 & $\begin{array}{l}\text { Mendengarkan } \\
\text { penjelasan } \\
\text { guru }\end{array}$ & 100 & 100 & 100 & 100 & 100 \\
\hline 2 & $\begin{array}{l}\text { Memperhatika } \\
\text { n video } \\
\text { pembelajaran }\end{array}$ & 100 & 100 & 100 & 100 & 100 \\
\hline 3 & $\begin{array}{l}\text { Mengerjakan } \\
\text { kegiatan } \\
\text { mencoba } \\
\text { dirumah sesuai } \\
\text { dengan } \\
\text { petunjuk } \\
\text { didalam video }\end{array}$ & 87 & 73 & 83 & 73 & 79 \\
\hline 4 & $\begin{array}{l}\text { Menanggapi } \\
\text { pertanyaan }\end{array}$ & 87 & 80 & 75 & 82 & 81 \\
\hline 5 & $\begin{array}{l}\text { Mengerjakan } \\
\text { latihan }\end{array}$ & 73 & 87 & 75 & 92 & 82 \\
\hline Presentase Akhir & & & $\begin{array}{l}\mathbf{8 8 , 4} \\
\mathbf{\%}\end{array}$ \\
\hline Kriteria & & & $\begin{array}{l}\text { Efe } \\
\text { ktif }\end{array}$ \\
\hline
\end{tabular}


299 Pengembangan Video Pembelajaran dengan Menggunakan Aplikasi Powerdirector 18 di Sekolah Dasar - Aulya Ilsa, Farida F, Mardiah Harun

DOI : https://doi.org/10.31004/basicedu.v5i1.643

Berdasarkan tabel diatas dapat disimpulkan bahwa hasil belajar untuk aspek sikap, pengetahuan, dan aspek keterampilan mendapatkan nilai tingkat pencapaian yaitu $85 \%$ sehingga dapat disimpulkan bahwa pembelajaran menggunakan video pembelajaran telah efektif dan dapat digunakan untuk pembelajaran disekolah yang lain. Peneliti mencobakan untuk menguji efektivitas untuk melihat hasil belajar peserta didik aspek pengetahuan pada SD Betha Plus Kota Padang dengan memperoleh tingkat pencapaian sebesar $85 \%$ dengan kategori efektif.

Hasil pengembangan video pembelajaran dengan mengikuti model Plomp dapat disimpulkan bahwa video pembelajaran memenuhi kategori valid, praktis dan efektif dalam memahami materi Lingkaran Matematika kelas VI SD. Hasil penelitian Lialy Sarti (2017) menyebutkan bahwa video pembelajaran dapat dijadikan sebagai sumber belajar bagi siswa dan sebagai inovasi pembelajaran bagi guru. Video pembelajaran membuat siswa bersemangat belajar. Belajar menjadi menyenangkan karena adanya animasi atau gambar yang menarik, siswa juga mudah memahami materi dengan video pembelajaran.

\section{SIMPULAN}

Video pembelajaran dengan menggunakan aplikasi PowerDirector 18 pada materi Lingkaran Matematika kelas VI SD dikembangkan mengikuti model umum desain penelitian Plomp dimana terdiri atas 3 tahap yaitu preliminary research, prothotyping phase, assessment stage.

Pada tahap preliminary research dilakukan validasi oleh diri sendiri, validasi oleh pakar. Hasil validasi dari pakar ahli diperoleh tingkat pencapaian yang termasuk kedalam kategori sangat valid. Selanjutnya tahap kedua yaitu prothotyping phase dimana video pembelajaran yang dikembangkan selanjutnya dilakukan uji one to one evaluation yang dilakukan kepada 3 orang siswa dan dilanjutkan setelah merevisi video pembelajaran dengan small group discussion yang dilakukan kepada 5 orang siswa. Selanjutnya diujikan di SDN 29 Koto hilalang Kecamatan Ampek Angkek Kabupaten Agam untuk melihat kepraktisan video pembelajaran dengan membagikan angket respon guru dan angket respon peserta didik tentang kepraktisan video pembelajaran materi lingkaran Matematika kelas VI SD.

Hasil pembagian angket respon praktikalitas kepada guru dan peserta didik tersebut diperoleh tingkat pencapaian yang termasuk kedalam kategori sangat praktis. Selanjutnya pada saat uji lapangan dilakukan penilaian terhadap hasil belajar dengan melihat aktivitas peserta didik dan hasil belajar dari aspek sikap, pengetahuan dan keterampilan. Untuk aktivitas peserta didik, aspek sikap, dan aspek keterampilan dapat dikatakan efektif, sementara untuk aspek pengetahuan diuji kembali di SD Betha Plus Kecamatan Kuranji Kota Padang dan diperoleh aspek pengetahuan dapat dikatakan efektif karena semua peserta didik memperoleh nilai 75\% diatas KKM yaitu 75.

Hasil penelitian pengembangan video pembelajaran materi Lingkaran Matematika kelas VI SD merupakan media pembelajaran yang baik untuk digunakan di sekolah dasar, apalagi dikondisi pembelajaran saat ini. Dimana guru tidak 
300 Pengembangan Video Pembelajaran dengan Menggunakan Aplikasi Powerdirector 18 di Sekolah Dasar - Aulya Ilsa, Farida F, Mardiah Harun

DOI : https://doi.org/10.31004/basicedu.v5i1.643

bisa bertemu secara langsung dengan peserta didik untuk memberikan pembelajaran disekolah disebabkan pandemi. Sehingga pembelajaran dilakukan secara daring dan luring. Hasil pengembangan video pembelajaran menunjukan video pembelajaran dapat mendorong pencapaian hasil belajar siswa secara maksimal serta dapat mengurangi kesulitan guru dalam proses pembelajaran secara daring ataupun luring.

\section{REFERENSI}

Basyiruddin. 2002. Media Pendidikan. Jakarta: Ciputat Press.

Daryanto.(2010). Media Pembelajaran. Yogyakarta: Gava Media

Hilna P, Luthfi H.M, Din.A.U. 2020. Analisis Proses Pembelajaran Dalam Jaringan (DARING) Masa Pandemi COVID-19 pada Guru Sekolah Dasar. Jurnal Basicedu Vol. 4 No. 4 Tahun 2020 Halm. 861-872.

Isrok`atun, R.Amelia. 2018. Model-model Pembelajaran Matematika. Jakarta : Bumi Aksara

JakaWarsihna. (2009). Pembuatan media video .Jakarta: Pusat Teknologi Informasi dan Komunikasi Pendidikan,Depdiknas.

Martini D.P, Edy B.I, Cholis S. 2016. Pengembangan Media Box Mengenal Bilangan Dan Operasinya Bagi Siswa Kelas 1 Di SD Negeri Gadang 1 Kota Malang. Jurnal Kajian Pembelajaran Matematika Vol.1 No 1.

Nana Sudjana. 2012. Penelitian Hasil Proses Belajar Mengajar. Bandung:PT.Remaja Rosdakarya

Plomp, Tjeerd. 2013. Educational Design Research: an Introduction. Netherlands: Netherlands Institute for Curriculum Development.

Purwanto. 2006. Evaluasi Hasil Belajar. Yogyakarta: Pustaka Pelajar

Riduwan. 2006. Dasar-dasar Statistika. Bandung: Alfabeta
Riyana, Cheppy. (2007). Metodologi Penelitian Kualitatif. Bandung: PT Remaja Rosdakarya.

Sanjaya, W. 2006. Strategi Pembelajaran Berorientasi Standar Proses Pendidikan. Jakarta : Kencana

S. Lialy. 2017. Pemanfaatan dan Sosialisasi Video Pembelajaran Berbasis Sparkol Videoscribe Pada Materi Matriks Sebagai Sumber Belajar Bagi Siswa san Sebagai Inovasi Pembelajaran Bagi Guru Kelas XI SMA/SMK di Jorong Kampung Padang Paraman Dareh, Nagari Aia Manggih, Kecamatan Lubuak Sikapiang, Kabupaten Pasaman, Provinsi Sumatera Barat dengan Metode SYIFW (Sharing to Youtube, Instagram, Facebook, dan WhatsApp). Jurnal Basicedu 2017

Sugiyono. 2013. Metode Penelitian Kualitatif dan Kuantitatif (R \& D). bandung: Alfabeta.

Taufik D.K. 2016. Pengaruh Penggunaan Media Video Pembelajaran Terhadap Prestasi Belajar Ilmu Pengetahuan Sosial Siswa Kelas V SD Se- Kecamatan Gedangsari Gunung Kidul Tahun Ajaran 2015/2016. Jurnal Universitas Sarjanawiyata Taman Siswa. (diakses online Agustus 2020)

Trianto.(2011).Model-model Pembelajaran Inovatif Berorientasi Konstruktivistik. Prestasi pustaka. Jakarta. 